\title{
Journal of Environmental \& Analytical Toxicology, Volume 6; Issue 5
}

\author{
Abdel-Tawab H Mossa* \\ Pesticide Chemistry and Toxicology, Environmental Toxicology Research Unit (ETRU), Pesticide Chemistry Department, National Research Centre, Giza, Egypt
}

The blissful contribution of nature in the form of environment has provided all types of remedies for human sufferings. It is only human being, who forgot what it was doing to its mother Earth during the quest to conquer natural resources. Years and years of uncontrolled activities have polluted Earth and filled its resources with harmful chemical and toxins. Now, the time has come when we have to pay for what our ancestors and we did. The deteriorating condition of the environment caused due to industrial revolution, incessant use of pesticides and mining, is now taking its toll on human body. The air that we breathe, the water that we drink and the land that we stand on are all polluted. Gradually these pollutants are trying to make their way into our bodies and eliciting harmful toxicological responses. Scientists are therefore trying to find out suitable solutions, remedial measures and preventive strategies that can help in controlling such toxic responses in humans. The Journal of Environmental \& Analytical Toxicology (JEAT) contributes to this process by publishing latest research developments in the field of toxicology. It also serves to ignite new ideas for research and development of better environmental strategies for the betterment of humankind. The current issue of the journal published such conceptual breakthroughs and latest findings, like phytoremediation of metal polluted soils with the help of native plant species, biological implications of exposure to pesticides, development of new advanced 3D cell models for assessing the impact of exposure to toxic chemicals etc. Some of the most important research articles published in the issue is discussed here.

Online retailing is a growing sector in almost all countries, especially in China. According to a survey conducted in 2014, about 14 billion shopping parcels are shipped in China. Though, the growth is considered a boon for Chinese economy, the associated adverse environmental implications of the same are yet to be realized. The current issue of the journal published an article by Zhang et al. [1], which highlighted the environmental impact of the waste generated from the packaging material used to pack the online bought merchandise to be shipped to faraway places. The waste generated in the process is often non-biodegradable and is thus a great threat to the Chinese society. The authors have rightfully highlighted the importance and severity of the issue with the help of statistical analysis.

The article published by Sobhi and Esrafili [2], presented a novel and highly effective method of double extraction of diphenylamine from fruit samples. The authors also highlighted the importance of GC-MS in the quantitation of the organic compound. The said study is highly important and will help in the standardization of the process of isolation of organic compounds like diphenylamine.

Soil and water pollution are two of the main factors that are responsible for the occurrence of most cases of heavy metal toxicity. Phytoremediation of soil with the help of native plant species is one of the best practices that can be followed to remove heavy metals from such polluted areas. Scientists across the world are hunting for potent bio remediating plant species. The article published by Kathal et al. [3], represented a similar effort. The authors studied the metal accumulating capacity of many native plant species viz. Saccharum, Brassica juncea,
Tamarix and Ricinus that were collected from various highly polluted sites of Delhi. The study is highly interesting and should be propagated to large scale.

The article by Samanta et al. [4], showcased the differences in the micro anatomical responses in Teleostean fish caused due to exposure to the herbicide almix. The most interesting thing is that, the authors made a comparative analysis of the changes when the fishes were exposed to the chemical in field with that of laboratory conditions. Interestingly enough, the results indicated that the fishes in field were better off than those in the laboratory i.e., anatomical and histological analysis revealed greater damages in the laboratory tested fishes. The article is a proof of the fact that results obtained from laboratory studies can't be implicated directly without testing it in real time conditions.

Similarly, estimating the exact in vivo implications of any Eco toxicological or pharmaceutical component via in vitro cell models is a challenging task and has many lacunae. The article published by Jeong et al. [5], addressed the same issue. The authors developed a 3D zebrafish liver cell model that was found to mimic in vivo conditions, better than the persisting $2 \mathrm{D}$ cell cultures. The authors substantiated the efficacy of their 3D model with the help of CYP1a1 activity and carbamazepine10,11-epoxide (CBZ-EP) assays. It was also proposed by the authors that, the model could be used to carry out extensive toxicological and pharmacological analysis in the future.

As far as metal toxicity is concerned, it has been established that people who work in the mines or even live in nearby areas are the worst affected. Furthermore, the condition becomes even worse due to the exposure to radionuclides found in the vicinity. The current issue published an article by Zakaria et al. [6], which investigated the concentration of natural radionuclides viz. 238U series, $232 \mathrm{Th}$ series and $40 \mathrm{~K}$ in the phosphate mines of El-Hamraween, El-Quser and Safaga, Egypt and the occupational hazards associated with it. The authors studied various physiological and biochemical parameters of the patients via the application of HPGe $\gamma$-spectrometry. Furthermore, the authors studied the concentration of heavy metals like As, Cd and $\mathrm{Pb}$ in the mine samples and in the blood of the mineworkers. The authors found that the concentrations were proportional and that they were dependent on age i.e., years of exposure. The study can be used as a model to analyze the physiological parameters of mineworkers elsewhere.

Water is the elixir of life but it can also be poison that can take lives. Therefore, it is highly important to pay heed to the quality of water we are consuming. The article published by Imneisi and Aydin

*Corresponding author: Abdel-Tawab H Mossa, Pesticide Chemistry and Toxicology, Environmental Toxicology Research Unit (ETRU), Pesticide Chemistry Department, National Research Centre, 33 El Bohouth Street, Dokki, Giza, Egypt, Tel: 202-33371211; Fax: 202-33370931; E-mail: abdeltawab.mossa@yahoo.com

Citation: Mossa ATH (2016) Journal of Environmental \& Analytical Toxicology Volume 6; Issue 5. J Environ Anal Toxicol 6: e108. doi: 10.4172/2161-0525.1000e108

Copyright: ๑ 2016 Mossa ATH. This is an open-access article distributed under the terms of the Creative Commons Attribution License, which permits unrestricted use, distribution, and reproduction in any medium, provided the original author and source are credited. 
Citation: Mossa ATH (2016) Journal of Environmental \& Analytical Toxicology Volume 6; Issue 5. J Environ Anal Toxicol 6: e108. doi: 10.4172/2161$0525.1000 \mathrm{e} 108$

[7], highlighted the same. The authors made a multifactorial water quality index calculation of the water collected from Karaçomak Dam. The same water is channeled to the entire city of Kastamonu city, Turkey, for drinking and all other purposes. The authors analyzed the Electrical Conductivity (EC), Temperature (T), pH, Total alkalinity, Dissolved oxygen (DO), Total hardness (Ha), Turbidity (TUR), Ammonia nitrogen $\left(\mathrm{NH}_{4}-\mathrm{N}\right)$, Nitrate nitrogen $\left(\mathrm{NO}_{3}-\mathrm{N}\right)$, Nitrite nitrogen $\left(\mathrm{NO}_{2}-\mathrm{N}\right)$, Phosphate $\left(\mathrm{PO}_{4}-\mathrm{P}\right)$, Chemical oxygen demand (COD) and Biochemical oxygen demand (BOD) and found that the water supplied was of poor standards and was not fit for drinking. Furthermore, the author highlighted the fact how discrepancies in the method of testing of water can sometimes show-misleading results. More importantly, drinking such misdiagnosed water is often the cause of water borne diseases in many remote places.

\section{References}

1. Zhang M, Chen $Y$, Shen $Y$ (2016) China's Environmental Threats of Internet Shopping Packaging Wastes. J Environ Anal Toxicol 6: 401.
2. Sobhi HR, Esrafili A (2016) A Double Extraction Method for Determination of Diphenylamine in Fruits by GC/MS. J Environ Anal Toxicol 6: 393.

3. Kathal R, Malhotra P, Kumar L, Uniyal PL (2016) Phytoextraction of $P b$ and Ni from the Polluted Soil by Brassica juncea L. J Environ Anal Toxicol 6: 394.

4. Samanta P, Pal S, Mukherjee AK, Senapati T, Kole D, et al. (2016) Gastrointestinal Pathology in Freshwater Fish, Oreochromis niloticus (Linnaeus) Under Almix Exposure. J Environ Anal Toxicol 6: 399

5. Jeong Y, Park CB, Baek IH, Jeong K, Baik S, et al. (2016) Differential Effects of CBZ-Induced Catalysis and Cytochrome Gene Expression in Three Dimensional Zebrafish Liver Cell Culture. J Environ Anal Toxicol 6: 404.

6. Zakaria KM, Atta ER, Ibrahim MS (2016) Assessment of the Heavy Metals and Natural Radioactivity in Phosphate Mines and Occupational Health Effects at Some Egyptian Regions. J Environ Anal Toxicol 6: 395.

7. Imneisi IB, Aydin M (2016) Water Quality Index (WQI) for Main Source of Drinking Water (Karaçomak Dam) in Kastamonu City, Turkey. J Environ Anal Toxicol 6: 407. 